\title{
Exploring children's understanding of the legal rights of suspects in England and Wales
}

Dr Vicky Kemp, Principal Research Fellow, University of Nottingham and Professor Dawn Watkins, Leicester Law School, University of Leicester

\begin{abstract}
While studies have explored adult suspects' understanding of their legal rights, seldom are the experiences of children and young people taken into account. In this article, we discuss findings arising out of research interviews conducted with 61 children and young people; many of whom have experience of being suspects. From listening to their points-of-view, we find that children and young people fundamentally lack understanding of the rights of suspects, and especially the inalienable nature of those rights. We argue this is not surprising when children are being dealt with in an adult-centred punitive system of justice, which is contrary to international human rights standards.
\end{abstract}

\section{Keywords}

children and young people, children's voices, rights respecting culture, suspects' legal rights, understanding

\section{Introduction}

In this article we discuss the findings of a study funded by the Legal Education Foundation, exploring children's understanding of their legal rights as suspects. The Police and Criminal Evidence Act (PACE) 1984 (and the associated Codes of Practice) regulate police powers in relation to the detention and questioning of suspects and, in this article we explore children's understanding of two key legal rights: to free legal assistance and the right to silence. ${ }^{1}$ With very little evidence from which to assess the effectiveness of these legal safeguards, this study focuses on children's understanding of these two rights, mainly from the perspective of young suspects.

The study was conducted by two researchers whose backgrounds and theoretical standpoints differ. They do, however, share a concern to bring the experiences of young suspects "out of the shadows and into the light" (Bevan, 2019, 316), so that their voices can help to influence change. We begin by outlining international human rights standards that are intended to provide legal protections for children when being dealt with by the police as a suspect, and a summary of the research literature which deals with children's understanding of these legal rights. Next is set out the research design and approach to data analyses, where we highlight the barriers faced by researchers seeking to access children, and young suspects in particular. While we find that children fundamentally lack an understanding of their legal rights as suspects, and especially the inalienable nature of those rights, we also find non-compliance with international human rights standards required for children in trouble with the law. In particular, instead of children being dealt with separately from adults, an adult-centred approach is seen to be adopted when dealing with all suspects within the secure environment of police custody and the police interview (Bevan, 2019; Kemp and Hodgson, 2016; Panzavolta et al., 2016; Hazel et al., 2002).

\section{Legal safeguards for young suspects}

It was following the wrongful conviction of three teenagers for the murder of Maxwell Confait in 1972, and a subsequent review of criminal procedures (Fisher, 1997; Royal Commission on Criminal Procedure, 1981) that PACE safeguards were implemented in 1986. Despite the safeguards having arisen due to concerns over the treatment and unfair

\footnotetext{
${ }^{1}$ While Code C of PACE (para. 1.5) uses the term 'juveniles' for 10 - to 17 -year-olds, we prefer to use the term 'children'.
} 
questioning of young suspects, the main concession as to age is the mandatory requirement for an appropriate adult to be involved. While free legal advice is available for all suspects, there is no mandatory requirement for a child to have a lawyer, even if being dealt with for a very serious offence. This means that from 10 to 17 years of age, children are dealt with in the same way as adults, including when being read their legal rights, despite obvious differences in emotional, mental and intellectual maturity (Bevan, 2019; Panzavolta et al., 2016). This is contrary to international human rights standards to protect children in the youth justice system, with the principal source being the United Nations Convention on the Rights of the Child (UNCRC).

The UNCRC requires a system of justice for children that is separate from adults and one in which the "best interests of the child" is "a primary consideration" in all actions concerning children (Article 3(1)). Article 40 incorporates the fair trial protections provided by Article 6 of the European Convention on Human Rights and guarantees children accused of a criminal offence the right to be "treated in a manner consistent with the promotion of the child's sense of dignity and worth" and which "takes into account the child's age and the desirability of promoting the child's reintegration and the child's assuming a constructive role in society" (Article 40(1)). In addition, the Council of Europe has issued Guidelines on 'Child-Friendly Justice' (2010) which guarantees the respect and effective implementation of all children's rights to the highest attainable level, taking into account the child's level of maturity and understanding of the circumstances of the case. While the Guidelines are not legally binding, they have been incorporated into EU Directive on Procedural Safeguards for Children who are Suspects or Accused Persons in Criminal Proceedings [2016/800]. ${ }^{2}$ More recently, the UN Committee on the Rights of the Child (2019) issued a new general comment (No. 24) intended to provide further explanation of specific rights outlined in the UNCRC and to guide countries in implementing youth justice systems that promote and protect children's rights. ${ }^{3}$

Despite the importance of human rights standards and legal safeguards for children when detained and interviewed by the police, very few studies have examined the precharge criminal process from the perspective of children. From studies that have included interviews with young suspects, following their release from police custody (when recollections have faded), many are seen to be confused about what is happening, and about their legal rights, and some comment on being put under pressure to respond to police questions (Bevan, 2019; Kemp and Hodgson, 2016; Hazel et al., 2002). From analysis of what was said during police interviews, concerns have also been raised over the dominance of the police in interrogations, with little contributions from appropriate adults or lawyers, who are intended to enhance legal safeguards (Kemp and Hodgson, 2016; Medford et al., 2003 and Evans, 1993). This lack of intervention by appropriate adults or lawyers is of concern, particularly when psychologists highlight how a child's maturity can affect their ability to instruct lawyers, that they are more likely than adults to confess, and confess falsely (Kassin et al., 2010). In relation to understanding their legal rights, it is known that many adults (including police officers), as well as children, do not understand the modified right of silence (Simm and Lamb, 2018; Kemp and Hodgson, 2016; Fenner et al., 2002; Clare et al., 1998).

\section{Research Design}

The project commenced in early October 2017 and was completed late December 2018. Ethical approval was received from the University of Nottingham in October 2017 to

\footnotetext{
2 The European Union funded a comparative study of procedural safeguards for young suspects to help inform minimum rules and guidelines for the proposed Directive. Kemp was responsible for conducting the fieldwork in England and Wales (see Kemp and Hodgson, 2016).

3 See Liefaard (2020) for further details of developments relating to 'child-friendly' justice and procedural safeguards for children in criminal proceedings.
} 
interview young suspects, although this did not allow us to enter into discussions over the details of the alleged offence(s). From the outset, we commenced our negotiations over access to young suspects, intending to engage with 130 children through a mix of focus groups and individual interviews, in five different sites. Long delays and rejections, however, necessitated changes to our research design. While initially we had the support of a governor from a HM Young Offender Institution (YOI), for example, our application to conduct research in a secure setting took over nine months to be considered, by which time the governor had left and permission was declined. Instead, we successfully negotiated access to a Secure Children's Home (SCH) and four focus groups were undertaken with ten children (between two and four in each group) and, subsequently, individual semi-structured interviews were held with nine of the young participants. The ten children involved in the $\mathrm{SCH}$ had experience of being a suspect in the criminal justice system.

Two Youth Offending Services (YOSs) were approached at the start of the project. In one area, after six months of discussing our proposal with senior managers, it was agreed that YOS workers would refer on to the researchers children they were working with who were willing to participate in this study. With a relatively low number of referrals forthcoming, we also approached children and young people who attended at a drop-in centre at the YOS, which included those without experience of being a suspect. The second YOS was undergoing a reorganisation and there were delays of 14 months before we were able to gain access to children. As it was only in the final month of the project that we could approach young suspects, we only achieved three research interviews. In total 45 children and young people were interviewed at the two YOSs, 27 who had experience of being a suspect and 18 who did not. ${ }^{4}$

Long delays were also experienced when seeking to negotiate access to looked after children, in care of the local authority. In one area, following a number of meetings with senior managers, it was agreed that the researchers could approach mangers of residential children's homes to see if children were willing to engage in this study. There then followed detailed discussions with the managers and six interviews were eventually undertaken at three different homes - one of the young participants having had experience of being a suspect. Despite a number of attempts to contact senior managers responsible for looked after children in the other area, no response was received.

Set out in Table 1 below is a brief description of the 61 children and young people involved in this study. Research interviews were conducted with 38 young suspects and 23 participants who did not have experience of being a suspect. ${ }^{5}$ Also noted is where the interviews took place, how many were involved in individual interviews or as part of a focus group. Also, when taking into consideration factors that are known to lead to the overrepresentation of children in the youth justice system, we included details of their ethnicity, whether they were looked after children, and if they reported mental health issues.

Table: Description of children and young people involved in this study
\begin{tabular}{|l|l|l|l|l|l|l|}
\hline $\begin{array}{l}\text { Where } \\
\text { interviewed }\end{array}$ & Suspects & $\begin{array}{l}\text { Not a } \\
\text { suspect }\end{array}$ & BAME & White & LAC & $\begin{array}{l}\text { Mental } \\
\text { health }\end{array}$ \\
\hline $\begin{array}{l}\text { SCH - individual } \\
\text { (9) and FGI (10) }\end{array}$ & 10 & - & 3 & 7 & 2 & 1 \\
\hline
\end{tabular}

\footnotetext{
${ }^{4} \mathrm{~A}$ small number of participants were aged over 17 years at the time of the research interviews but all those dealt with by the police as a suspect were aged under 18 years at that time.

5 Of the 61 individual participants, four boys were aged 12 to 14 years, 16 males and 12 females aged 15-16 years and 17 males and 12 females aged 17 to 21 years. There were 28 male and 10 female suspects and nine males and 14 females who did not have experience of being a suspect.
} 


\begin{tabular}{|l|l|l|l|l|l|l|}
\hline In care - individual & 1 & 5 & 4 & 2 & 6 & 1 \\
\hline YOS - individual & 19 & 3 & 9 & 13 & 5 & 1 \\
\hline YOS - FGI & 8 & 15 & 5 & 18 & 2 & 2 \\
\hline Total & 38 & 23 & 21 & 40 & 15 & 5 \\
\hline
\end{tabular}

BAME: Black, Asian and minority ethnic; FGI: Focus Group Interviews; LAC: Looked after children; $\mathrm{SCH}$ : Secure Children's Home; YOS: Youth Offending Service.

As Table 1 demonstrates, we have gathered data from a diverse group of children, with their experiences ranging from having minimal or no contact with the police, to having multiple arrests and/or having served a custodial sentence.

We used a child-friendly topic guide when conducting focus groups and individual interviews. A sequenced set of open-ended questions was intended to help bring out the perceptions of children in relation to their understanding of the legal rights of suspects. While generally helpful in guiding the conversation in a child-friendly way, there were occasions where the researcher had to deviate from the topic guide, mainly due to responses received covering more than one question, which led to some questions being asked 'off-script'. Coded references are used to ensure the anonymity of the participants involved. 6

\section{Approach to Data Analysis}

As stated in the 'Introduction' section, the study was conducted by two researchers whose backgrounds and theoretical standpoints differ. Watkins conducts research into children's understanding of law in their everyday lives (Watkins et al., 2019, Watkins et al., 2018; Watkins et al., 2016) and a notable feature of her work is its emphasis on theories of play and the use of digital gaming as a research tool. Watkins' work is informed by the socalled new sociology of childhood (James et al., 1998; James and Prout, 1997; StaintonRogers, 1989), purposely seeking to privilege the voice of the child when identifying key themes in the data.

In addition to researching the legal rights of adult suspects, and developing an app to help inform suspects of their legal rights (Kemp, 2020), Kemp has also undertaken research with young suspects (Kemp and Hodgson, 2016; Bottoms and Kemp, 2007). Having a detailed knowledge of this research field, at least from an adult's perspective, Kemp was aware that issues raised by children would require further analysis. Accordingly, while seeking to adopt Glaser and Strauss' $(1967,1)$ 'grounded theory' (or theory constructing) approach, in "the discovery of theory from the data", she recognised that she would not be entering the field neutrally, as she already had in mind a number of themes arising from a deductive approach that she wanted to explore in more depth. Drawing on Layder's $(1998,2)$ 'adaptive theory' approach, which focuses on generating social theory in conjunction with ongoing empirical research, this enabled a multi-layered approach to be adopted when analysing the data.

Both researchers adopted a thematic analysis, which is "a method for identifying, analysing and reporting patterns (themes) within data" (Braun \& Clarke, 2006 at 79). They both used NVivo, a computer analysis tool which assists with managing and interpreting qualitative data. The attributes of the research participants can be coded in NVivo, which

\footnotetext{
6 The coded reference begins with the initial of where the interview took place: $\mathrm{S}$ for the $\mathrm{SCH}, \mathrm{Y}$ for YOS, and $L$ for looked after children. The number of the interview then follows and the letter $F$ indicates if this was a focus group interview. For YOS interviews, the initial ' $a$ ' or ' $b$ ' has been added to indicate the geographical area in which the interview was conducted. When using quotations from the research interviews, the sex of the participant is noted, either ' $M$ ' for male or ' $F$ ' for female, followed by whether they were a suspect or not, using the abbreviations ' $S$ ' or 'NS'.
} 
was helpful when cataloguing responses from children based on whether or not they had experience in the youth justice system and, if so, to what extent.

For Watkins, initial codes were 'data-derived' in the sense that they focused on describing the content of the data; and from here a more interpretive approach was taken; seeking to identify implicit meanings within the data. She used 'semantic' and 'latent' codes; with semantic codes frequently mirroring the language and ideas put forward by the participants, whereas latent codes "go beyond the explicit content of the data" to identify "the assumptions and frameworks that underpin what is said in the data" (Braun and Clarke, 2013, 207). In short, the aim of Watkins' analysis was not only to identify what children have said in relation to their knowledge of the rights of young suspects; but to interrogate the assumptions they are making in their communication of that knowledge. Watkins' approach when analysing the data can be described as 'theoretical' as opposed to 'inductive' thematic analysis; coding has been carried out with regard to the specific research question "what are children and young people's understandings of their rights as suspects?" and its aim has been to provide a "detailed analysis of some aspect of the data" rather than a "rich description of the data overall" (Braun and Clarke, 2006, 84). Significantly, the researcher's (inevitable) subjectivity is acknowledged and embraced as a valuable part of the qualitative research process here; albeit tempered by the researcher giving ongoing, critical attention to the role that her experiences and assumptions is playing in the research process (a 'personal reflexivity' (Braun and Clarke, 2013,37)).

The themes discussed below arise out of Watkins' initial analysis of the data, followed by a further analysis of these key issues undertaken by Kemp.

\section{Part I: A lack of understanding of the nature of suspects' legal rights}

There is a list of information that the police have to provide to young suspects at the start of a police interview; including informing them of the right to legal assistance and the right to remain silent. In relation to the latter right, officers will read out the modified caution which states, "You do not have to say anything. But it may harm your defence if you do not mention when questioned something which you later rely on in Court. Anything you do say may be given in evidence" (PACE Code C, para. 10.5(b)). This is a complicated form of words that many adults (Fenner et al., 2002) and children do not understand (Simm and Lamb, 2018). While some police officers will simply ask young suspects if they understand the caution, others will go through the caution in more detail and ask questions to check their understanding (Kemp and Hodgson, 2016, 132-133). The overall conclusion of this study is that children lack a fundamental understanding of these two rights, and especially the inalienable nature of the rights. This can be seen when examining two main themes identified in the data; 'ambivalence regarding rights' and 'powerlessness'.

\section{Ambivalence regarding rights}

In Watkins' initial coding, she identified that when children were asked if they know what legal rights suspects have, many participants were able to name specific rights, for example:

M/S: For me, you've got the freedom of speech and the right to security so you can't get injured here or anything. They've basically just said you've got a right to a phone call. We can't do anything bad to you (L4).

F/S: You've got the right to ring someone. You've got the right to have some food and drink, and you've got the right to complain about something...You've got the right to 
contact a solicitor because obviously if you're under 18 that means you'll probably get free Legal Aid... (Y23Fa). ${ }^{7}$

F/NS: If you're under the age of 18 you're allowed an adult (Y26Fa).

F/NS: You don't have to speak until you have a lawyer present (Y27Fa).

However, when giving their views concerning the exercise (or potential exercise) of these rights, we identified that our participants' responses tended to be dependent on factors such as the seriousness of the offence, the characteristics of the suspect, and whether they were innocent or guilty of the offence they were suspected of committing. The extracts below demonstrate this in relation to the right to have a lawyer:

F/S: I don't really think for some people a solicitor would make a difference because of their crime. But for some people who are like first time, or who haven't been in trouble before, they don't really know much about it. They definitely need a solicitor, so the solicitor will like break things down to them and make them feel comfortable enough to know what they need to be saying (Y23Fa).

F/NS: If you got arrested for something you didn't do then obviously you need to get a solicitor. If it was your intention to shoplift...If you know you're stealing, then what's the point of wasting money on a solicitor when you're in the wrong (Y25Fa). ${ }^{8}$

F/NS: If you haven't done anything then you don't feel the pressure to get one [a lawyer], because you don't need anyone else to fight for you (Y27Fa).

F/S: Some people don't think they need one [a lawyer], but I would always have one. If you haven't done anything then you don't need a solicitor (S7).

Rights tended be seen then as options to be chosen or rejected, depending on the circumstances; rather than fundamental and inalienable entitlements attaching to the person, irrespective of circumstances. ${ }^{9}$ As such, possessing knowledge of a right by no means translates into making a positive choice to exercise it. For example:

M/S: If you're being accused of something then you've got a right to a lawyer, solicitor, advocate to speak on behalf of you. I never have a lawyer (L4).

M/S: I didn't have a solicitor. It depends on how you're feeling. If you don't know what to do in the interview, or don't know what to say, that's when you get a solicitor. It depends on what the incident is. If it was serious I'd have a solicitor but not for something minor (Y28Fa).

This theme of ambivalence regarding rights was identified also in other contexts in the data; for example, in discussions with looked after children concerning access to information about rights. When one participant was asked if he had seen people being told about their legal rights on television, he said (M/NS), "I'm not really interested in it to be honest" (L2). When another participant was asked if young people should be better informed about their legal rights, and whether this was something that interested him, he replied (M/NS), "I guess so yeah" (L1).

\footnotetext{
7 Young respondents either used the term 'solicitor' or 'lawyer' to describe those who provide legal advice.

8 The participant was 20 years old.

9 There were similar findings in Bevan's (2019) study of young suspects and in a recent study of adult suspects (Kemp, 2020).
} 
In interviews with participants who did not have experience of being a suspect, they were asked questions about the minimum age of criminal responsibility. Many were shocked to hear that from 10 years of age a child can be arrested and detained by the police, with most saying that the age should be raised to 12 or 14 years. ${ }^{10}$ One participant commented on needing to take into account the seriousness of the offence when determining the age of criminal responsibility, when saying (F/NS), "It would depend on the circumstances of what it actually is" (Y27Fa). When asked if they had someone come to their school to talk about their rights, the two participants in the focus group replied (F/NS), "I think so, probably a few years ago", (F/NS) "In primary school, yeah I think I did" (Y27Fa).

\section{Concerns over the cost of a lawyer}

Underlying some of the ambivalence noted by Watkins, Kemp identified concerns arising over the costs of having a lawyer. When one participant was asked if it was worth having a lawyer, for example, she replied (F/NS), "I don't think it is. If you know you're stealing, then what's the point of wasting money on a lawyer when you're in the wrong really" (Y25Fa). ${ }^{11}$ There was a strong perception, particularly amongst those who did not have experience of being a suspect that you have to pay for a lawyer. ${ }^{12}$ In one focus group, for example, two participants commented on the importance of cost when responding to the question of whether they would have a lawyer if arrested:

F/NS: I'd probably have one but it's just money wise, you're not going to have no money are you?

M/NS: - I wouldn't have one because I'd be broke at the end of it (Y26Fa).

In another focus group interview with three participants, all thought that you have to pay for a lawyer. The main reason given was because lawyers are known to be expensive and that they would not work for free. For example, when asked if he would have to pay for a lawyer, a participant who had been arrested by the police replied:

M/S: You probably have to pay like shit, because it's a court like isn't it? You're distracting them from their other work. They've got court cases and they have to leave this to come and sort you out. So clearly you're going to have to pay a shit ton of money so that they can make up for their money that they've lost (Y29Fa).

Similarly, in an individual interview another participant commented that he did not have a lawyer at the police station because (M/S), "I couldn't afford it at the time." He went on to say, "I know you can get like pro bono ones now that are free. But at the time [over a year ago] I didn't have that much knowledge" (Y31Fa).

\section{Understanding not improved by experience}

For Kemp, it was notable but not surprising, that the demonstrated lack of understanding of suspects' legal rights included participants who had experience of being arrested and detained by the police. ${ }^{13}$ There were a number of young participants who had been arrested on many occasions but seemed to be confused about their legal rights. This was the response from a 17-year-old persistent offender when asked to comment on his rights:

M/S: They can ask you questions. See if you allegedly saw something. If you had this on you, or something. To see if you would like to contact someone. They ask where

\footnotetext{
10 The Committee on the Rights of the Child (2019) has recently commended to Member States to impose a minimum age of criminal responsibility at 15 or 16 years (para. 22).

11 The participant was 21 years old.

12 As noted above, some young participants felt that legal advice was only free for those aged under 18 years.

13 There were similar findings in research undertaken with adult suspects (Kemp, 2020).
} 
you're from and how you're feeling. It's free to have a solicitor. The appropriate adult should be your mum, she will come and help you and make sure you understand everything (Y7a).

In addition, as noted above, this was the response from a young participant when asked about the legal rights of suspects, "For me, you've got the freedom of speech and the right to security..." (L4). When further asked to comment on suspects' legal rights, he said that these included:

M/S: The prohibition of torture and slavery, the right of security. The rights of all your stuff, and basically they'll tell you that this will happen, that will happen (L4).

When seeking to clarify the legal rights of suspects, he did say that, if arrested, the police would contact his parents, and that he had a right to a telephone call. When prompted about legal advice, he said that he knew about this right but that he never has a lawyer. Instead, despite having been dealt with for serious offences, he said it was his grand dad, acting as his appropriate adult, who gave him legal advice. This is despite PACE making it explicit that it is the lawyer, and not the appropriate adult, who provides legal advice.

\section{Gathering information from TV}

When further exploring the theme of ambivalence when considering children's attitudes towards their legal rights, it is important to note that many participants said that they got information from television programmes. A couple of participants, one having experience of being a suspect and the other not, said that they got their information from watching old episodes of 'The Bill', a fictional show about a police station, first broadcast in 1984 ( $\mathrm{S} 12 \mathrm{~F}$ and $\mathrm{Y} 10 \mathrm{a})$. When asked how they would respond to police questions, this participant said (F/NS), "Can't you say no comment?...I've just seen it on TV" (L3) and another one replied (M/NS), "I don't know where I got it from, I just know about it. I probably got it from the TV" (L5). Both these participants (aged 16 and 17 years) were looked after children. With the police sometimes attending at the children's home in response to incidents reported by staff, it is of concern that they do not know suspects' rights, particularly as statistics show that looked after children are overrepresented in the youth justice system (Barnardos, 2017).

More generally, participants commented on getting information about suspects' legal rights when watching popular US 'cop' series. For one participant, who had been arrested by the police on a number of occasions, for example, when asked where people should go to get information about their legal rights, she replied (F/S), "Everybody needs to watch more about NCIS and CSI and all of that because listen, they tell you a lot" (Y23Fa). When asked if she thought that people should have a lawyer if arrested by the police, she replied:

F/S: It depends if you want one or not. It also depends on what crime you've been accused of. If it's something minor, you probably won't need one as much, but you will if you've been accused of murder or something like that (Y23Fa).

Of course, TV programmes are not a good source of information, particularly US 'cop' shows, as the legal rights of suspects are different to those in England and Wales. In addition, popular 'cop' shows sensationalise serious offences, such as murder and rape, which can give people the impression that other, more mundane offences, are not so serious and, as such, a lawyer is not required. This was a perception noted above, when some participants commented on why they would not have a lawyer if arrested for a minor offence. As this participant put it:

M/NS: If it was a serious incident then obviously you would have a solicitor...It depends on what the incident was. You can do a shoplifting yourself or wait until your parents 
come in. A serious offence is when you've been like stabbing or something...A burglary (Y24Fa).

It is of concern that children are drawing information about the legal rights of suspects from fictional television programmes, rather than having access to public legal education. This is particularly so when such programmes lead to misconceptions and misunderstandings about suspects' legal rights, which can lead to uninformed decisions being made when children are arrested and/or interviewed by the police. In a number of interviews, for example, participants, without having experience of being a suspect, said that they would not have a lawyer if dealt with by the police for an offence of shoplifting (Y24Fa, Y25Fa and Y27Fa), despite the detrimental impact that a criminal sanction can have on their future lives. ${ }^{14}$

\section{Powerlessness}

For Watkins, the theme of powerlessness relates to the ways in which participants in this study described their experiences of arrest and detention. In the following example, the powerlessness of the young suspect arose when the police arrived early in the morning at her home to make the arrest:

F/S: They came really early, like probably seven or something. So, I wasn't awake, but they were rushing me and swearing at me saying hurry up...They raided my house and arrested me from there... There were loads of officers in my house (S10F).

The next three comments are examples of powerlessness commented on by participants when held in police custody:

M/S: And then they'll ask you a bunch of questions as to why you were doing what you were doing, why you're in this situation, what's been happening. And after that they'll tell you what's going to happen, how it's going to happen...And they'll, basically what you say will be then used as evidence to the situation. You don't have to say anything. And then you'll go into, and they'll say this is an interview room, and they'll put you in there and they'll say we need to question you... They'll say whatever you say will be recorded for the purposes of the court (L4).

M/S: The officer behind the counter was talking, I got to sign a couple of things. Then they searched us to see if we'd got anything. And they put us in a cell... While I was in the cell and then when they came I went into an interview room (S11F).

F/S: Then they took my handcuffs off, and then cautioned me again and made me sign these things...They booked me in, took my name and all of that and asked if I wanted a solicitor. They put me in the cells and then they interviewed me (S12F).

As demonstrated in the extracts earlier; these experiences are commonly expressed in the third person plural; 'they' lead the action, in striking contrast to the entirely passive role of the participants.

\section{Retaliating against the police}

It is in relation to feeling frightened and anxious about what is happening when they are taken into police custody, and the feeling of powerlessness, that can lead to some participants 'kicking off', to try and disrupt or frustrate the police. For one participant, he commented on his behaviour in police custody when saying:

M/S: You're put in a cell because they don't know what else to do with you. You're put there for your safety, and for the safety of others, and until further things are going to

${ }^{14}$ A number of adult detainees also commented that they would not have a lawyer if being dealt with for what they perceived to be a minor offence (Kemp, 2020, 134). 
happen. But when you're put in the cell it feels like you're being punished, locked away for a bit, and that you've just done something bad. I can't sleep in a place like that. I just sat there going crazy for a while. I then started shouting and pressing the buzzer and things like that (L4).

Another one commented, "I just get bored so I keep pressing the buzzer, playing games with them [the police]" (Y22b).

When detained against their will, and having to spend a long time in a cell with nothing to do, other participants accepted that this could lead to them 'kicking off', particularly if they did not feel that they were being treated fairly. ${ }^{15}$ This was an issue arising in a $\mathrm{SCH}$ focus group, when two participants discussed how they were sometimes treated unfairly the police:

F/S: If you're kicking off, you need to go to your cell, and they start going mad at you and that.

Researcher: What happens when you kick off?

F/S: One time I asked them for a drink when I was getting booked in and it took ages and ages... They threw me on the floor and I was going mad. I needed a drink because I had a dry mouth and they said I can't have a drink. The next girl comes through and she was asked if she would like a drink. One of the officers started laughing, ha, ha, and he told me that I couldn't have one. I was only 13 then (S12F).

For some participants who have experience in the criminal process, it seems that in response to the sense of powerlessness, they can put on an act of bravado, however, some appeared overconfident in their ability to make informed decisions. Giving 'no comment' responses in the police interview can be one way of trying to disrupt the police but such a tactic can also increase vulnerability, particularly if the young suspect does not understand what is happening, and the consequences of decisions they make. While making 'no comment' might demonstrate confidence, therefore, it can lead to negative consequences, particularly in cases where a lawyer might have advised their client to make a response, at least to some police questions. ${ }^{16}$

Coupled with the sense of powerlessness, questions are raised about the extent to which young suspects are held for a long time in police custody, often without adult support, other than the contact they have with the police. Indeed, it has been noted that the appropriate adult and, if involved, the lawyer, tend to arrive at the custody suite when the police are ready to conduct the interview, which can be many hours following their detention (Bevan, 2019; Kemp and Hodgson, 2016). Apart from the mandatory involvement of an appropriate adult, which is often a parent or guardian who has little or no experience of police interviews, in a number of areas there is often no other support available for children while being dealt with at the police station. There are local authority areas where the Youth Offending Services (YOS) directly provide appropriate adult services, which can lead to a youth justice practitioner being involved in supporting young suspects but, in many cases, appropriate adult services are provided by volunteers (Kemp and Hodgson, 2016). This is not the situation in court cases, when children are dealt with separately from adults in the 'youth court' and YOS officers are available to deal with all cases.

\section{Inability to complain}

\footnotetext{
15 There were similar findings in Kemp and Hodgson's study of young suspects (2016).

16 In cases where there is an alibi, or a potential defence, for example. Also, without making an admission, young suspects cannot be diverted from court, even though diversion is a priority within the UNCRC (Kilkelly, 2008).
} 
Participants in the $\mathrm{SCH}$ commented on feelings of powerlessness when it is a matter for the police how they are treated. Having been detained for many hours, for example, this participant said (M/S), "They wouldn't allow me to go and have a shower, the exercise yard, or anything" (S11F). The feeling of powerlessness often meant that even though they felt that they had not been dealt with fairly, they could not complain. As this one remarked (M/S), "Even if I was treated unfairly, I'm the one that's done bad, so I feel like I shouldn't really complain" (S10F). While one of the four participants in this focus group felt that it was reasonable for the police to treat him unfairly, because he considered custody to be part of his punishment, another one took exception to this saying (F/S), "But why should we be treated bad? How do they know if a certain person's guilty of doing what they've been charged with?" She was then asked if she would complain if she was treated badly, but highlighting her feeling of powerlessness she said, "I feel like it's a waste of time, because it won't get nowhere further and you waste your own time in complaining about it. I don't think anything would happen" (S10F).

\section{Part II: The right to silence and 'no comment' responses}

It is in this context that their different perspectives generated the most discussion between the researchers. During her initial coding, Watkins coded references to and experiences of 'no comment'. She noted that replying 'no comment' to police questions seems to be frequently advocated by lawyers representing children, and it is accepted by police; albeit subject to strong challenge in some circumstances. As the following participants commented:

\section{F/S: My lawyer told me to say 'no comment' (Y23Fa).}

$\mathrm{M} / \mathrm{S}$ : The police were trying to pressure me saying, 'we know it was you, you were there, you were such and such'. They can't say I was because I said 'no comment' (S1).

Watkins subsequently identified within the 'no comment' category two themes 'agency' and 'confidence' and on this basis she suggests that children's understanding of and attitude to the right to silence stands as a notable example of a right that can be clearly understood and powerfully exercised by them. By contrast, drawing on her experience of the criminal justice system, Kemp is sceptical of Watkins' conclusions. Kemp argues that, with the exception of a small number of young suspects who have extensive experience of being arrested and detained by the police, the confidence and agency identified by Watkins may actually be merely superficial. Further, she argues, this apparent exercise of agency by children can be detrimental to their best interests.

\section{Confidence}

Whereas under the theme of powerlessness Watkins identifies a tendency for participants to describe 'they' leading the action, we see by contrast here participants describing events in the first or second person and (apparently) demonstrating confidence in their ability to take control of an actual or envisaged situation:

M/S: ...said no comment, which was amazing. I did, I said no comment for everything (L4).

M/S: The police can't put me under pressure to say something when my solicitor isn't there because I just go 'no comment'. I know what I'm doing (S1).

Kemp points out that these comments are made by children who have been drawn into an adult-centred system of justice in which they actually have little or no control. And while some children can be confident, or perhaps overconfident, of making 'no comment' replies to police questions, as noted above, this is not always in their best interests. Indeed, in an earlier study of police custody, Kemp $(2013,18)$ observed two separate cases, involving a 17- and 18-year-old, where they both declined legal advice after having 
been arrested on suspicion of murder, saying that they would make 'no comment', without having spoken to a lawyer.

\section{Agency}

In practical terms, the exercise of the right to say 'no comment' of course offers participants an opportunity to take control of an interview situation by refusing to speak. Drawing on Giddens' definition of agency as "a continuous flow of conduct ... of an agent..." [whereby] at any point in time, the agent "could have acted otherwise" (Giddens, 1979, 55-56), Watkins identified as significant within this 'no comment' category of data the exercise of choice on the part of the participants, rather than merely taking the opportunity to say nothing. Indeed, even where a small number of participants described 'saying nothing' they do so in ways that demonstrate apparently strong levels of self-control and self-determination. The following comments highlight the sense of agency that participants, all from the $\mathrm{SCH}$, feel in the police interview, despite having a lawyer with them:

F/S: I said no comment to everything. My solicitor said I could go no comment but I told her I was doing it anyway (S4).

F/S: No one said anything in the interview, not my lawyer or my appropriate adult because I just said 'no comment'. I told them my name and then said 'no comment'. It was easy just saying 'no comment' because I do it in all my interviews (S12F).

M/S: Basically they [lawyers] put it to you like it's best you listen to them, but you can go no comment or see what you want to do anyway (S10F).

Kemp acknowledges this sense of agency but she is also conscious of the unequal relationship that operates when young suspects have been arrested and detained within a secure environment, within which the police are dominant. There is also an imbalance of power in the interview, with police interviewers being in a strong position, particularly when knowing the strength of evidence against the suspect, or the lack of any evidence. It has been shown how police interviewers, when faced with 'no comment' responses, can try to put young suspects under pressure to respond to their questions (Bevan, 2019; Kemp and Hodgson, 2016). One tactic, mentioned by a number of young participants in this study, was for the police to repeat the same questions. As this young participant remarked, "They can ask you the same question about three or four times" (Y21b).

In relation to the right of silence, common tactics adopted by the police to try and encourage young suspects to respond to their questions is to ask them to 'tell the truth', or to point out in a 'no comment' interview, that they are surprised the suspect has not taken the opportunity to protest their innocence (Bevan, 2019; Kemp and Hodgson, 2016). Of the 38 young suspects in this study, around three-quarters said that they had been told by the police to 'tell the truth', with almost two-third saying that they made 'no comment' responses. However, it can be difficult for young suspects to maintain 'no comment' replies, particularly if they are without a lawyer and the police put them under pressure to respond to their questions. This was the situation in one case when a participant commented on the pressure the police put him under to answer their questions when saying:

M/S: For 40 minutes I went 'no comment' but then they cracked me. They said 'did you put a knife to someone's throat?' I said I just pointed it at him. They said that a witness said I had put it to his throat. But I hadn't. I took responsibility for what I'd done. I did point the knife at him (Y17a).

This comment was made by a 16-year-old looked after male. After first being arrested and interviewed for this offence, he was asked to return to the police station for a voluntary 
interview. ${ }^{17} \mathrm{He}$ did request legal advice but was told that he would have to be taken into custody to get a lawyer, and so he declined. His care worker acted as his appropriate adult and he reportedly did not intervene when the young suspect was put under pressure by the police to respond to their questions. Having been convicted at court for possessing a bladed weapon, he was placed on an Attendance Centre Order. It is important, therefore, to examine the context within which young suspects might feel confidence and agency when making 'no comment' replies, as ultimately they are still acting within an environment that is controlled by the police.

The right of silence is an important protection for suspects against self-incrimination but the caution was modified in 1994. Subsequent studies have shown how many adults do not understand the caution (Fenner, et al., 2002), with 48 per cent of police officers in one study failing to explain all three sentences of the modified caution correctly (Clare et al., 1998, 327). While studies examining understanding of the modified caution have not included young participants, Simm and Lamb (2018) examined how the right of silence was presented to young suspects when focusing on police interviews. While the purpose of the caution is to explain suspects' right to silence and to protect them from selfincrimination, the findings suggest that the caution may not safeguard suspects as intended. In particular, they found that police officers delivered the caution at a speed that is likely to be too fast for young suspects to comprehend (Simm and Lamb, 2018, 869).

Kemp, therefore, does not concur with Watkins' view of the right of silence as a significant exception to the more general lack of understanding of the nature of rights. On the contrary, when considering the complexity of the modified caution, she argues it is difficult to see how children are able to make informed decisions when making 'no comment'. Instead, Kemp's perception is that while some young suspects seem to speak with authority when making 'no comment', this can be used as a form of protest against the police. That is, knowing how frustrating for the police it can be when they do not respond to their questions. Without legal advice, however, such a strategy might not be in the best interests of the child, on the contrary, it could lead to more severe outcomes in cases.

\section{Part III: Creating a consistent, rights-respecting culture}

While Kemp and Watkins disagree concerning the extent to which participants' awareness and exercising of the right to silence represents an exception to the more general lack of understanding of the nature of rights identified in the study, they do agree that participants' references to and discussions to the right to silence are significant. At the very least, they agree that in contrast to other rights, participants were aware of the right to silence and are generally unambivalent about exercising it, even though they mainly learn of this right from television shows.

Drawing on literature regarding the development of understanding of rights in schools (Robinson, 2014), it is clear that one of the most effective ways to improve children's understanding of their rights is through the development of a culture whereby those rights are consistently respected and applied in practice. As we have seen the right to silence may be challenged but is acknowledged by the police and persistently advocated by lawyers acting on a child's behalf.

In contrast, participants' ambivalence concerning their 'other' rights corresponds to an apparent lack of consistency among police in respecting those rights:

Researcher: Were you treated well by the police?

17 This is a formal interview under caution with suspects being entitled to free legal advice. 
M/S: Sometimes. It depends. I'm not going to say that all officers are like twats and that, I've met some that are alright. It just depends - it also depends on the offence. If it's for something serious they come and get you and use force straight away (Y18a).

Researcher: And how was the police officer with you?

M/S: He was all right. I knew who the officer was, I'd spoken to him before.

F/S: You can get some police officers that are horrible to you ... You can be lucky if you get nice police officers as well. Because I've seen most police officers just chuck people on the ground and search them (Y24Fa).

M/NS: And then when the police come here [children's home] I'm just respectful. When the police talk to me it's normally just disrespect, and I'm sat there talking to them trying to be respectful, and it's just they're not really caring so much in my surroundings or disrespectful to the people that I live with and that (L5).

There were a number of occasions when participants were commenting on how they were treated by the police, where we identified a lack of consistency in police officers respecting their rights. Highlighting such ambivalence are comments made by two participants when talking about how they were sometimes treated fairly by the police and, at other times not:

M/S: They gave me food and that.

F/S: They let me out [of the cell] and tell me about getting out [released from custody], and sometimes they're nice to you. You say oh I need to have a shower mate, and they'll let you have a shower (S12F).

Later on they said:

F/S: They start laughing at you when you're in the cell because you just start kicking off. I was going mad as they wanted to extend my time ${ }^{18}$... Then they just start laughing, they said I think I knew everything and I don't, and then they walked off.

$\mathrm{M} / \mathrm{S}$ : The police were racist to me. I kept asking them for the time and one officer said that he can't keep coming down to tell me the time. I asked again for the time and he started calling me a dirty Paki and that. So I threw the hot drink at him (S12F).

When asked if he wanted to make a complaint over the racist language used, he replied saying, "There's no point because I swore and threw the hot chocolate at him" (S12F). Without an effective mechanism through which suspects can report their experiences, it is not known more widely how they are treated while detained.

\section{Conclusion}

In this article we have demonstrated a general lack of understanding among our young participants concerning not just the rights of children as suspects but the inalienable nature of these rights. We have identified the right to silence as an apparent exception to this and we rely on it as an example of a right that is widely known and respected and exercised by participants - albeit within a context that does not as yet provide assurance that the right is being exercised appropriately and/or with full knowledge of the potential consequences. We conclude by suggesting that the most powerful and effective way to educate children about their rights (both as suspects and more generally) is to create and maintain a culture in which those rights are consistently and overtly respected.

Certainly, this may be achieved through the imposition of internationally recognised standards and procedures, but it must also be informed by the views and experiences of children themselves. It is notable that when seeking to engage with children who have

18 Under PACE, the police have 24 hours in which to deal with a suspect but this can be extended to 36 hours on the authorisation of a superintendent. 
experience of having been a suspect, we faced significant challenges in accessing them, and even when this was achieved, our ethical approval prohibited us from talking about the circumstances surrounding their arrest, or any other personal details relating to their alleged offences. These restrictions made it extremely difficult to engage with children at times, particularly those who were wanting to talk about their experiences in relation to the alleged offence and/or their personal circumstances.

It is therefore heartening to report that Kemp, Lesley Laver and Nicola Carr have been awarded funding from the Nuffield Foundation to examine the impact of PACE on the detention and questioning of young suspects. And for the first time in England and Wales, this research will include engaging with children about their legal rights in 'real time' that is, while they are being held in police custody. It is already known that children who are suspects often come from backgrounds marked with social exclusion, poverty and family difficulties, with many being looked after children or on the 'at-risk' register (Arnull et al., 2005). Indeed in her review, Bevan (2019, 24-29) describes "a perfect storm of interlinked vulnerabilities" that "also intersect with the vulnerability every detainee experiences by virtue of their detention, in the total control of the officers in the custody suite" (2019, 29). The forthcoming research will further explore these interlinked vulnerabilities, at the same time as exploring children's understanding of their legal rights, and how they exercise those rights. The research team will also examine how demanding the custody process is for children, and how substantially these additional vulnerabilities can affect their ability to cope with detention and engage effectively with the interview process (Bevan, 2019).

\section{References}

Arnull, E., Archer, D., Eagle, S., Gammampila, G., Johnston, V., Miller K. and Pitcher, J. (2005) Persistent Young Offenders: A Retrospective Study (London: Youth Justice Board).

Barnardos (2017) Children in Trouble with the Law (London: Barnardos).

Bevan, M. (2019) Children and Young People in Police Custody (London: PhD thesis, London School of Economics).

Bottoms, A. and Kemp, V. (2007) 'The relationship between Youth Justice and Child Welfare in England and Wales', in M. Hill et al. (eds) Youth Justice and Child Protection (London: Jessica Kingsley).

Braun, V. and Clarke, V. (2013) Successful Qualitative Research (London: Sage).

Braun, V. and Clarke, V. (2006) 'Using thematic analysis in psychology', Qualitative Research in Psychology, 3:2, 77-101.

Clare, I., Gudjonsson, G. and Harari, P. (1998) 'Understanding the Current Police Caution (England and Wales), Journal of Community and Applied Social Psychology, 8(5), 323329.

Committee on the Rights of the Child (2019) General Comment No 24 on Children's Rights in the Child Justice System, UN Doc CRC/C/GC/24.

Council of Europe (2010) Guidelines of the Committee of Ministers of the Council of Europe on Child-Friendly Justice (Strasbourg: Council of Europe).

Evans, R. (1993) The Conduct of Police Interviews with Juveniles, Royal Commission on Criminal Justice, Research Study No. 8 (London: HMSO).

Fenner, S., Gudjonsson, G. and Clare, I. (2002) 'Understanding the Current Police Caution (England and Wales) Among Suspects in Police Detention, Journal of Community and Applied Social Psychology, 12(2), 83-93. 
Fisher, Sir H. (1977) Report of an inquiry by the Hon. Sir Henry Fisher into the circumstances leading to the trial of three persons on charges arising out of the death of Maxwell Confait and the fire at 27 Doggett Road, London SE6 (London: HMSO).

Giddens, A. (1979) Central Problems in Social Theory: Action, Structure and contradiction in social analysis (London: Macmillan Press).

Glaser, B. and Strauss, A. (1967) The Discovery of Grounded Theory: Strategies for Qualitative Research (New York: Aldine Publishing).

Hazel, N., Hagell, A. and Brazier, L. (2002) Young Offenders' Perceptions of their Experiences in the Criminal Justice System (London: Policy Studies Institute).

James, A., Jenks, C. and Prout, A. (1998) Theorizing Childhood (Cambridge: Polity Press). James, A. and Prout, A. (eds) (1997), Constructing and Reconstructing Childhood (2nd ed.), (Abingdon: Routledge).

Kassin, S., Drizin, S., Grisso, T., Gudjonsson, G., Leo, R. and Redlich, A. (2010) 'PoliceInduced Confessions: Risk Factors and Recommendations', Law and Human Behaviour 34(1), 3-38.

Kemp, V. (2020) 'Digital Legal Rights: Exploring Detainees' Understanding of the Right to a Lawyer and Potential Barriers to Accessing Legal Advice', Criminal Law Review 2, 129147.

Kemp, V. (2013) Bridewell Legal Advice Study: Adopting a 'Whole-Systems' Approach to Police Station Legal Advice' (London: LSRC).

Kemp, V. and Hodgson, J. (2016) 'England and Wales: Empirical Findings', in M. Vanderhallen et al. (eds) Interrogating Young Suspects: Procedural Safeguards from an Empirical Perspective (Intersentia: Cambridge). Available at: https://papers.ssrn.com/sol3/papers.cfm?abstract_id=2980339.

Kilkelly U (2008) Youth justice and children's rights: measuring compliance with international standards. Youth Justice 8(3): 187-192.

Layder, D. (1998) Sociological Practice: Linking Theory and Social Research (London: Sage).

Liefaard, T. (2020) 'Child-friendly justice and procedural safeguards for children in criminal proceedings: New momentum for children in conflict with the law?', Bergen Journal of Criminal Law and Criminal Justice, 8/1, 1-17.

Medford, S. Gudjonsson, G. and Pearse, J. (2003) 'The efficacy of the appropriate adult safeguard during police interviewing', Legal and Criminological Psychology 8(2), 253266.

Panzavolta, M, de Vocht, D, Hodgson, J, Kemp, V, Vanderhallen, M and van Oosterhout, M (2016) 'Integrated analysis' in M Vanderhallen et al. (eds) Interrogating Young

Suspects II: Procedural Safeguards from an Empirical Perspective (Cambridge: Intersentia).

Robinson, C. (2014) Children, their Voices and their Experiences of School: What Does the Evidence Tell Us? (Cambridge: Cambridge Primary Review Trust).

Royal Commission on Criminal Procedure (1981) Report and Law and Procedure (London: HMSO).

Simm, M. and Lamb, M. (2018) 'An Analysis of How the Police 'Caution' is Presented to Juvenile Suspects in England', Psychology, Crime and Law, 24:8, 1-22. 
Stainton-Rogers, R. (1989) 'The Social Construction of Childhood' in W. Stainton-Rogers, D. Harvey and E Ash (eds) Child Abuse and Neglect (Milton Keynes: Open University Press).

Watkins, D, Law, E. and Barwick, J. (2019) 'Being home alone and babysitting: responsibility, competency and risk', Child and Family Law Quarterly, 2.

Watkins, D., Law, E., Barwick, J. and Kirk, E. (2018) 'Exploring children's understanding of law in their everyday lives', Legal Studies 1-20.

Watkins, D., Law, E., Barwick, J. and Kirk, E. (2016) 'If you are 10 you go to prison: Children's Understanding of the Age of Criminal Responsibility', Northern Ireland Legal Quarterly, 67(3).

\section{Author biographies}

Vicky Kemp is a principal research fellow in the School of Law at the University of Nottingham. Her research involves examining police custody and access to police station legal advice, with a particular focus on the experience of children and young people as suspects in the criminal justice system.

Dawn Watkins is a professor of Law at the University of Leicester. Her research involves drawing on theories of play to both measure and improve children and young people's 'legal capability' - or in other words, their ability to deal effectively with law-related issues they encounter in their day to day lives. 